ВІСНИК

ОДЕСЬКОГО НАЦІОНАЛЬНОГО

МОРСЬКОГО УНІВЕРСИТЕТУ

№ 3 (63), 2020
HERALD

OF THE ODESSA NATIONAL

MARITIME UNIVERSITY № 3 (63), 2020

УДК $629.5 \mathrm{E30}$

DOI 10.47049/2226-1893-2020-3-51-75

\title{
АНАЛИЗ ПЕРСПЕКТИВ СТРОИТЕЛЬСТВА НОВЫХ РЕЧНЫХ КРУИЗНЫХ СУДОВ
}

\author{
А.Г. Егоров \\ к.т.н., ст. научн. сотрудник \\ Морское инженерное бюро, Украина, Одеса
}

\begin{abstract}
Аннотация. Показана важность речного туризма. В настоящее время отмечается заметная тендениия дифференцирования услуг. Европейский бизнес предлагает теперь не просто стандартные услуги, но и старается выделить каждый тур каким-либо особенным решением, например, особой кухней, классической музыкой, возможностью проводить концертно-развлекательные мероприятия и т.n.

Тенденции на отечественном рынке вполне соответствуют европейскому, где с 2013 года происходит динамичный рост числа круизов, прежде всего, за счет американских туристов. Европейский речной круизный рынок является самым большим (41\% всех речных круизных судов приходится на Европу). Флот на реке Нил значителен, но из-за политической нестабильности в регионе стагнирует. Флот круизных судов в России продолжает сокращаться и стареть. В Америке и Азии (в основном, Китай) количество речных судов растет, но незначительно.

Утилизачия «старых» серий отечественных речных круизных судов не только идет, но и идет с нарастающими темпами. Пик ее пришелся на 2011-2018годы, и этот проиесс продолжается и сейчас. Общая пассажировместимость круизных судов, при этом, снижается как за счет списания судов, так и за счет уменьшения числа мест при повышении комфортабельности во время переоборудования. Практически все суда в той или иной степени были переоборудованы или модернизированы.

Число отечественных речных круизных пассажирских судов $к$ 2025 году сократится почти на 30 \%, до 87 единии (с учетом нового флота). К 2030 году его количество может уменьшиться до 53 судов без учета судов, которые могут быть построены. Для сохранения понятия «речной круиз», и не только для иностранных туристов, рекомендуется на среднесрочную и долгосрочную перспективы строительство новых пассажирских судов, которые бы наиболее полно удовлетворяли запросам рынка.
\end{abstract}

Ключевые слова: речной круиз, речное круизное пассажирское судно, проектное решение, анализ, сравнение, прогноз.

(C) Егоров А.Г., 2020 
ВІСНИК

ОДЕСЬКОГО НАЦІОНАЛЬНОГО

МОРСЬКОГО УНІВЕРСИТЕТУ
HERALD

OF THE ODESSA NATIONAL

MARITIME UNIVERSITY

УДК $629.5 \mathrm{E30}$

DOI 10.47049/2226-1893-2020-3-51-75

\title{
АНАЛІЗ ПЕРСПЕКТИВ БУДІВНИЦТВА НОВІТНІХ РІЧКОВИХ КРУЇЗНИХ СУДЕН
}

\author{
О.Г. Сгоров \\ к.т.н., ст. наук. співпрацівник \\ Морське інженерне бюро, Україна, Одеса
}

\begin{abstract}
Анотація. Показано важливість річкового туризму. На даний час відзначається помітна тендениія диференціювання послуг. Європейський бізнес пропонує тепер не просто стандартні послуги, а й намагається виділити кожен тур будь-яким особливим рішенням, наприклад, особливою кухнею, класичною музикою, можливістю проводити концертнорозважальні заходи і т.n.

Тендениії на вітчизняному ринку ицілком відповідають європейському, де з 2013 року відбувається диналічне зростання числа круїзів, перш за все, за рахунок американських туристів. Свропейський річковий круїзний ринок є найбільшим (41\% всіх річкових круїзних суден припадає на Європу). Флот на річиі Ніл значний, але через політичну нестабільність в регіоні перебуває в стагнації. Флот круїзних суден в Росії продовжує скорочуватися і старіти. В Америиі і Азї (в основному, Китай) кількість річкових суден зростає, але незначно.

Утилізачія «старих» серій вітчизняних річкових круїзних суден не тільки йде, але i йде з наростаючими темпами. Пік ї̈ припав на 20112018 роки, і ией прочес триває $і$ зараз. Загальна пасажиромісткість круїзних суден, при иьому, знижується як за рахунок списання суден, так $i$ за рахунок зменшення числа місиь при підвищенні комфортабельності під час переобладнання. Практично всі судна в тій чи іншій мірі були переобладнані або модернізовані.

Число вітчизняних річкових круїзних пасажирських суден до 2025 року скоротиться майже на $30 \%$, до 87 одиниць (з урахуванням нового флоту). До 2030 року його кількість може зменшитися до 53 суден без урахування суден, які можуть бути побудовані. Для збереження поняття «річковий круїз», $і$ не тільки для іноземних туристів, рекомендується на середньострокову $i$ довгострокову перспективи будівництво нових пасажирських суден, які б найбільш повно задовольняли запитам ринку.
\end{abstract}

Ключові слова: річковий круїз, річкове круїзне пасажирське судно, проектне рішення, аналіз, порівняння, прогноз. 
UDC 629.5 E30

DOI 10.47049/2226-1893-2020-3-51-75

\title{
ANALYSIS OF PERSPECTIVES OF BUILDING OF NEW RIVER CRUISE VESSELS
}

\author{
A. Egorov \\ Candidate of Technical Sciences, Senior Researcher \\ Marime Engineering Bureau,Ukraine, Odessa
}

\begin{abstract}
The importance of river tourism is shown. As for now there is a noticeable trend towards differentiating services. European business now offers not just standard services, but also tries to highlight each tour with some special solution, for example, special cuisine, classical music, opportunity to carry out concert and entertainment events, etc.

Trends in domestic market correspond with the European one, where since 2013 there has been dynamic growth in the number of cruises, primarily due to American tourists. The European river cruise market is the largest (41\% of all river cruise ships are in Europe). The fleet on the Nile River is significant, but due to political instability in the region, it is stagnating. The cruise ship fleet in Russia continues to shorten and aging. In America and Asia (mainly China), the number of river vessels is growing, but not significantly.

Utilization of the «old» series of domestic river cruise ships is not only proceeding, but is also proceeding at an increasing pace. It peaked in 20112018, and this process continues now. At the same time, the total passenger capacity of cruise ships decreases both due to the decommissioning of ships and due to a decrease in the number of seats while increasing comfort during refitting. Almost all vessels have been re-equipped or modernized to one degree or another.

The number of domestic river cruise passenger ships by 2025 will be reduced by almost $30 \%$, to 87 units (including the new fleet). By 2030, its number may be reduced to 53 ships, excluding ships that can be built. To preserve the concept of «river cruise», and not only for foreign tourists, it is recommended for the medium and long term to build new passenger ships that would most fully meet the market demands.
\end{abstract}

Keywords: river cruise, river cruise passenger vessel, design solutions, analysis, comparison, prognosis.

Постановка проблемы. Речные круизы являются популярной разновидностью туризма и развиты во всем мире. Помимо существующих круизов в Европе, США, Китае, Египте, России, Украине появляются новые круизы по новым маршрутам Европы (включая Беларусь, Португалию, Францию), Южной Америке, Вьетнаму, Камбодже, Сибири и т.п. Кроме диверсификации круизов, повышается также качество самих речных круизных пассажирских судов (РКПС). Всё это - результат учета 
потребностей клиентов, которые становятся более требовательными к уровню обеспечения отдыха.

Временное отступление в виде ограничений по COVID-19 присутствует, но уровень и последующий рост культурного туризма в целом и речного круизного в частности, безусловно, возобновится уже к 2022 году, поэтому изучение общих тенденций создания РКПС в мире представляется важным и имеющим реальный интерес для судостроения и компаний - операторов РКПС.

Целью статьи является выявление тенденций в современном речном круизном бизнесе, как основы для создания перспективных концептов новых речных круизных пассажирских судов для отечественных условий.

Изложение основного материала. Российский и украинский рынки круизных услуг являются частью общеевропейского туристического бизнеса. Самая доходная часть ориентирована именно на въездной туризм, как правило, на немцев, американцев, австралийцев, англичан, французов, китайцев.

Тенденции на отечественном рынке вполне соответствуют европейскому, где с 2013 года происходит динамичный рост числа круизов, прежде всего, за счет американских туристов. Сводные данные 2019 года по мировому флоту РКПС представлены в таблице 1.

Таблица 1

Распределение речных круизных судов по регионам мира

\begin{tabular}{|c|c|c|c|c|c|}
\hline Год & Европа & Россия & Африка & Другие регионы & Всего \\
\hline 2005 & 177 & 166 & 282 & 100 & 725 \\
\hline 2010 & 216 & 150 & 286 & 95 & 747 \\
\hline 2015 & 318 & 130 & 275 & 114 & 837 \\
\hline 2019 & 359 & 113 & 280 & 114 & 866 \\
\hline Общий прогноз & Рост & Снижение & Нейтральный & Нейтральный & Рост \\
\hline
\end{tabular}

Источник: $[1 ; 2 ; 3 ; 4]$

Европейский речной круизный рынок является самым большим (41\% всех РКПС приходится на Европу). Флот на реке Нил значителен, но из-за политической нестабильности в регионе стагнирует [1]. Флот РКПС в России продолжает сокращаться и стареть [4]. В Америке и Азии (в основном, Китай) количество речных судов растет, но незначительно [1].

В 2016 году на внутренних водных путях Европы было выполнено 1,36 млн. речных круизов, на 2,7 \% больше по сравнению с предыдущим годом.

Однако при этом сам европейский пассажирский флот имеет свои особенности. В последние годы наиболее интенсивно развивается рынок каютных судов, и потенциал судов данного типа до сих пор не исчерпан, 
собственно, как и потенциал прибрежных экскурсионных судов, так и судов для однодневных прогулок в тех районах, где речной туризм не получил ещё должного развития.

В 2016 году в Европе было введено в эксплуатацию 20 новых речных КС из 31 во всем мире. Из них 9 судов для системы Рейн - Майн Дунай (на 1591 пассажиров), 3 для Рейна (на 440 человек), 3 для Дуная (на 434 человека), 2 - для Дору (Португалия, на 202 человека), 2 - для Сены и Роны и одно - для Эльбы.

В 2017 году были сданы 5 судов для Рейна, 3 судна для системы Рейн - Майн - Дунай, 4 - для Дору, 2 - для Дуная, 2 - для Сены и Роны и одно - для Эльбы. Всего 17 судов, при этом почти половина новых КС (47 \%) были построены не для Рейна - Майна - Дуная, а для Дору, Роны и Сены.

Эта диверсификация также имеет место в самом Рейне: маршруты поездок для реки круизы были расширены на притоки Рейна. С точки зрения операторов эта диверсификация экономически обоснована, так как концентрация круизов на одной реке рискованна. Особенно это касается новых судов, стоимость постройки которых достаточно велика. Изменяется не только географический охват, но и тематика круизов, в том числе ориентированных на более молодую аудиторию.

Кроме того, наблюдается расширение классического навигационного периода для европейских рек (240 дней). Например, на зимний сезон 2011-2012 годов была разработана специальная круизная программа по Рейну, которая включала в себя шестидневный приключенческий, семидневный рождественский и восьмидневный новогодний круизы.

В настоящее время отмечается заметная тенденция и дифференцирования услуг. Европейский бизнес предлагает теперь не просто стандартные услуги, но и старается выделить каждый тур каким-либо особенным решением, например, особой кухней, классической музыкой, возможностью проводить концертно-развлекательные мероприятия и т.п. Такие подходы позволяют создать особые условия для каждой конкретной группы людей в зависимости от их образования, возраста, культурного уровня.

Например, Viking River Cruises специально ориентировал свой бизнес на граждан США старше 55 лет со средними доходами, численность которых в США составляет около 99 млн. человек. В результате $86 \%$ клиентов речных круизов Viking это американцы, а остальные граждане Великобритании и Австралии.

Строительство новых РКПС в Европе продолжается.

В 2018 году было сдано 10 РКПС и 3 судна были существенно модернизированы, включая одно переоборудование из грузовой баржи.

Например, в 2018 году прошел реновацию РКПС «Johann Strauss» длиной 110 м на 144 пассажира в 72 каютах (Standard 12 м², Deluxe Cabins $15 \mathrm{~m}^{2}$, Suites $19,5 \mathrm{~m}^{2}$ ). 
Вообще существует некая общая неформальная закономерность РКПС строится на 50 лет по корпусу и машине с реновацией через 10 лет по гостинице и ресторану и через 5 лет по навигационному оборудованию.

В 2019 году построили 20 новых круизных судов.

Основными заказчиками новых речных КС являются немецкие, швейцарские и американские компании.

Например, в 2011 году банк Ipex, входящий в государственный банковский консорциум Германии KfW, и швейцарский банк UBS взяли на себя финансирование $75 \%$ стоимости заказа (срок действия кредита 8,5 лет) на строительство 5 РКПС абсолютно нового концепта «Рейн макс» класса Viking Long Ship (см. рисунок 1) для швейцарской судоходной компании Viking River Cruises, которые были построены на судоверфи в Ростоке и поставлены к сезону эксплуатации 20122013 годы.

Эта компания уже на март 2020 год имела 58 Viking Long Ship (длина 135 м, 190 пассажиров / 95 кают), причем первая пятерка себя окупила. В 2019 году Viking River Cruises, которая начала работать только в 1997 году, уже имела шесть морских судов и 72 РКПС, в том числе в Украине, России, Китае. Строит суда для реки Миссисипи (на 386 пассажиров) и экспедиционные для Великих Озер (два по 378 пассажиров). 16 Viking Long Ship работают на Дунае, три Viking Long Ship - на Сене, одно - на Гароне. Два РКПС пассажировместимостью по 98 человек на Эльбе и четыре по 106 пассажиров - на Дору.

Продолжительность рейсов - от 6 до 23 дней. «Большой Европейский Тур» Будапешт - Амстердам в системе Дунай - Майн - Рейн длится 15 дней. Тур «Лион и Прованс» по Роне -8 дней. Тур «Речные пути Царей» из Москвы в Санкт-Петербург - 13 дней.

Для судов, работающих в системе Рейн - Майн - Дунай, лимитирующая длина 135,0 м (ранее 110,0 м), ширина - 11,4 м.

Теперь практически все новые РКПС имеют пассажировместимость до 180-200 человек с габаритной длиной «Рейн макс» класса 135 метров (в 2012 году было заказано наибольшее количество судов), суда пассажировместимостью 160-180 человек занимают второе место среди заказов с 2011 года и спрос на них стабилен.

Тенденция к судам с повышенной пассажировместимостью объясняется тем, что компании стремятся распределить высокие эксплуатационные расходы на большее количество пассажиров, чтобы избежать повышения цен на круизы, при этом качество круиза заметно выросло за счет увеличения размеров площадей кают за счет дополнительных 25 метров длины. 
ВІСНИК

ОДЕСЬКОГО НАЦІОНАЛЬНОГО

МОРСЬКОГО УНІВЕРСИТЕТУ

№ 3 (63), 2020
HERALD

OF THE ODESSA NATIONAL

MARITIME UNIVERSITY

№ 3 (63), 2020
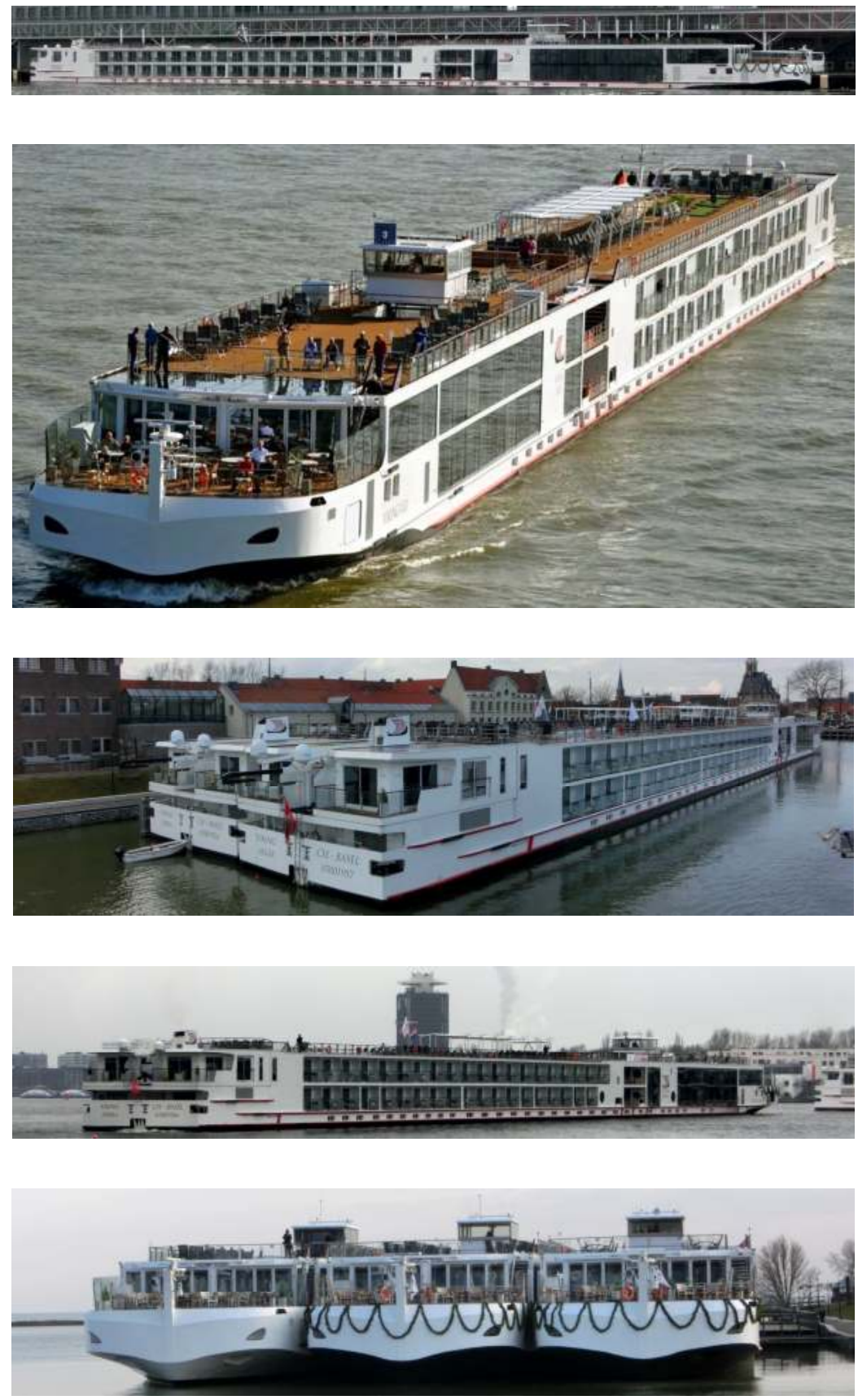

Pис. 1. Фото Viking Long Ship. Построено 58 судов с 2012 по 2020 годы Длина 135 м. 190 пассажиров / 95 кают. Источник: [Viking River Cruises] 
Для внутренних водных путей Европы из-за определяющих ограничений ширины и высоты судна (габариты шлюзов и мостов) характерны двухпалубные РКПС с относительно малой шириной, которая, кстати, создает достаточно большие проблемы для размещения кают (вплоть до несимметричности расположения балконов, коридоров и т.П., что характерно для Viking Long Ship).

Но для судов, работающих только на Рейне или только на Дунае, ширина может быть увеличена вплоть до $22 \mathrm{м}$, а также возрастает надводный габарит в зависимости от района эксплуатации.

Их можно охарактеризовать как самоходные плавучие гостиницы. На палубах надстройки, как правило, отсутствуют проходы по бортам. Самая верхняя палуба (Sun Deck) часто оборудуется бассейном и съемными (для обеспечения надводного габарита судна) тентами от солнца. Палубы с целью рационального использования внутренней площади выполняются, как правило, закрытыми, а для прогулок используют Sun Deck. Прогулки возможны только по этой палубе, нахождение на открытом воздухе - также на открытой веранде ресторана «аля карт» в носовой части салона (практически на баке) и на балконах тех кают, где он есть.

Гостиничные пространства включают в себя пассажирские каюты, рестораны, места отдыха, бары, магазины, солнечные и прогулочные палубы, а также пространства, обеспечивающие связь между ними, т.е. коридоры, залы, лестницы и лифты. Сюда же входят помещения для обслуживающего персонала (служебные помещения, камбуз, кладовые, прачечные) и экипажа (каюты, кают-компании, комнаты отдыха).

На РКПС последних лет постройки, работающих на реках Западной Европы под флагами Германии, Голландии и Швейцарии, суммарная площадь помещений пассажирского блока составляет 61-71 \% (для сравнения, на эксплуатирующихся ныне в России и Украине судах 43-50 \%). Понятно, что низкий коэффициент полезного использования площадей признак меньшей эффективности судна.

Принятая организация досуга на борту судна и берегового экскурсионного обслуживания предусматривает односменное питание пассажиров, в отличие от двухсменного, широко применяемого ранее на отечественных судах. Для проведения широких общественных мероприятий хотя бы один из салонов (ресторан) имеет посадочную вместимость близкую к полной пассажировместимости судна. Особую роль играет носовой салон, который обеспечивает клиентам наилучший обзор окрестностей. В ряде случаев для тех же целей взамен носового салона используется открытая верхняя палуба Sun Deck.

На европейских РКПС стандартные каюты, как правило, двухместные, при необходимости могут трансформироваться в одну двуспальную. В каждой каюте обязательно имеется индивидуальный душ и туалет, телевизор, холодильник, имеется доступ к интернету, установлен телефон 
спутниковой связи. Часто имеется балкон для индивидуального пользования.

Размеры кают зависят от категории. В стандартной категории размер каюты составляет 14-15 м², в категории повышенной комфортности - 18-25 м².

Ha Viking Long Ship на 190 пассажиров 25 стандартных кают площадью $14 \mathrm{~m}^{2}$, 22 каюты с «французскими» балконами (лоджиями) площадью $12,5 \mathrm{~m}^{2}, 39$ кают с балконами площадью $19 \mathrm{~m}^{2}$, семь люксов площадью 25,5 $\mathrm{m}^{2}$ и аппартамены 41,3 $\mathrm{m}^{2}$.

Интересно отметить, что есть и более «премиальные» версии, например, РКПС Uniworld Super Ship «SS. Antoinette» постройки 2011 года, на котором при той же длине «Рейн макс» 135 м 152 пассажира в 59 каютах или «AmaVerde» со 162 пассажирами в 81 Suite.

Заметно выросла площадь общественных помещений, приходя-

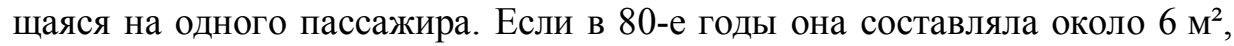
то в XXI веке она увеличилась до 8-12 $\mathrm{m}^{2}$. Можно рекомендовать также выбор площадей ресторана и обзорного салона, исходя из $1,6 \mathrm{~m}^{2}$ и 1,8-1,9 м² на одного пассажира соответственно.

Существует на европейских реках и принципиально иные архитектурно-конструктивные решения РКПС. Например, составные суда, состоящие из секции с судовой энергетической установкой и ходовым мостиком и секции с жилыми и общественными помещениями. Суда этого типа не только обеспечивают более комфортные условия по уровням шума и вибрации, но и имеют широкие возможности по продлению эксплуатационного периода.

При этом среднее число пассажиров на РКПС длиной 110 метров 140 человек, экипажа с обслуживающим персоналом - 25-35 (в России и Украине численность экипажа на такую же численность пассажиров примерно в полтора раза больше). Минимальный состав экипажа для европейских круизных каютных судов, согласно требований Центральной комиссии судоходства по Рейну, приведен в таблице 2.

Для европейских РКПС, соответствующих гостинице 3-4-х звездочного уровня, отношение количества пассажиров к общему количеству экипажа и обслуживающего персонала находится в диапазоне 4-5; для 5-ти звездочных - 3,2-3,5. См. пример для РКПС типа Viking Long Ship при 190 пассажирах в таблицах 3 и 4.

Такая численность обусловлена тем, что в Европе очень активно применяется совмещение профессий (это касается в первую очередь гостиницы), а также автоматизацией СЭУ, автоматизацией палубных работ (автоматические якорно-швартовные лебедки), автоматизацией процесса погрузки припасов и механизацией процесса уборки палуб (моечные машинки и т.п.). 
ВІСНИК

ОДЕСЬКОГО НАЦІОНАЛЬНОГО МОРСЬКОГО УНІВЕРСИТЕТУ № 3 (63), 2020
HERALD

OF THE ODESSA NATIONAL

MARITIME UNIVERSITY № 3 (63), 2020

Основное отличие между экипажами КС в Европе и России - в численности палубной команды - на 3 человека и машинной команды на 10-12 человек.

Отечественный рынок круизных услуг является частью общеевропейского туристического бизнеса. Некоторые европейские компании (Viking River Cruises) имеют свои дочерние компании в России и Украине, а остальные работают через ведущих отечественных туроператоров (Мостурфлот, Водоход, Донинтурфлот, Инфофлот и др.).

Несмотря на наличие судов с недостаточным уровнем комфортабельности, речной круизный флот европейской части России (до 2020 года) и Украины (до 2014 года) загружен практически на все $100 \%$ и дальнейший рост круизного рынка сдерживался ограничением предложения мест на речных круизных судах (см. таблицу 5).

Таблииа 2

Минимальный состав экипажа для европейских круизных каютных судов (Центральная комиссия судоходства по Рейну)

\begin{tabular}{|c|c|c|c|c|c|c|c|c|c|}
\hline \multirow[t]{3}{*}{ № } & \multirow[t]{3}{*}{ Группа } & \multirow[t]{3}{*}{ Специальность } & \multicolumn{7}{|c|}{$\begin{array}{c}\text { Количество членов экипажа в зави- } \\
\text { симости от режима эксплуатации } \\
\text { и стандарта на оборудование } \\
\text { (степени автоматизации) S1/S2 }\end{array}$} \\
\hline & & & \multicolumn{3}{|c|}{$\begin{array}{c}14 \text { часов } \\
\text { в сутки }\end{array}$} & \multicolumn{2}{|c|}{$\begin{array}{c}18 \text { часов } \\
\text { в сутки }\end{array}$} & \multicolumn{2}{|c|}{$\begin{array}{l}24 \text { часа } \\
\text { в сутки }\end{array}$} \\
\hline & & & $\mathrm{S}$ & & $\mathrm{S} 2$ & S1 & S2 & S1 & $\mathrm{S} 2$ \\
\hline \multirow{7}{*}{1} & \multirow{7}{*}{$\begin{array}{l}\text { Допустимое } \\
\text { количество } \\
\text { спальных } \\
\text { мест: до } 50\end{array}$} & Судоводитель & 1 & & 1 & 2 & 2 & 3 & 3 \\
\hline & & Рулевой & & & & & & & \\
\hline & & Старший матрос & 1 & & & & & & \\
\hline & & Матрос первого класса & & & & 1 & & 1 & \\
\hline & & Матрос второго класса & & & 2 & & 1 & & 1 \\
\hline & & Механик или моторист & 1 & & 1 & 1 & 1 & 1 & 1 \\
\hline & & Всего & 3 & & 4 & 4 & 4 & 5 & 5 \\
\hline \multirow{7}{*}{2} & \multirow{7}{*}{$\begin{array}{l}\text { Допустимое } \\
\text { количество } \\
\text { спальных } \\
\text { мест: } \\
\text { от } 51 \text { до } 100\end{array}$} & Судоводитель & 1 & & 1 & 2 & 2 & 3 & 3 \\
\hline & & Рулевой & 1 & & 1 & & & & \\
\hline & & Старший матрос & & & & & & & \\
\hline & & Матрос первого класса & 1 & & & 1 & & 1 & \\
\hline & & Матрос второго класса & & & 1 & & 1 & & 1 \\
\hline & & Механик или моторист & 1 & & 1 & 1 & 1 & 1 & 1 \\
\hline & & Всего & 4 & & 4 & 4 & 4 & 5 & 5 \\
\hline \multirow{7}{*}{3} & \multirow{7}{*}{$\begin{array}{l}\text { Допустимое } \\
\text { количество } \\
\text { спальных } \\
\text { мест: более, } \\
\text { чем } 100\end{array}$} & Судоводитель & 1 & 1 & 1 & 2 & 2 & 3 & 3 \\
\hline & & Рулевой & 1 & 1 & 1 & & & & \\
\hline & & Старший матрос & & & & & 1 & & 1 \\
\hline & & Матрос первого класса & 2 & 1 & 1 & 3 & 1 & 3 & 1 \\
\hline & & Матрос второго класса & & 2 & 1 & & 1 & & 1 \\
\hline & & Механик или моторист & 1 & 1 & 1 & 1 & 1 & 1 & 1 \\
\hline & & Всего & 5 & 6 & 5 & 6 & 6 & 7 & 7 \\
\hline
\end{tabular}


ВІСНИК

ОДЕСЬКОГО НАЦІОНАЛЬНОГО

МОРСЬКОГО УНІВЕРСИТЕТУ

№ 3 (63), 2020
HERALD

OF THE ODESSA NATIONAL

MARITIME UNIVERSITY

№ 3 (63), 2020

Таблииа 3

Состав экипажа на Viking Long Ship при 190 пассажирах

\begin{tabular}{|c|c|c|}
\hline Количество & Должность & Размещение \\
\hline 1 & Капитан & Одноместная каюта \\
\hline 1 & Старший помощник & Одноместная каюта \\
\hline 1 & Старший механик & Одноместная каюта \\
\hline 3 & Матрос & Двухместная каюта \\
\hline 1 & Второй механик & Двухместная каюта \\
\hline
\end{tabular}

Таблий 4

Состав обслуживающего персонала (гостинищь) на Viking Long Ship при 190 пассажирах

\begin{tabular}{|c|c|c|}
\hline Количество & Должность & Размещение \\
\hline 1 & Отель менеджер & Одноместная каюта \\
\hline 1 & Директор круиза & Одноместная каюта \\
\hline 1 & Шеф-повар & Одноместная каюта \\
\hline 46 & $\begin{array}{c}\text { Обслуживающий } \\
\text { персонал }\end{array}$ & $\begin{array}{c}19 \text { двухместных каюты } \\
\text { и пульмановских каюты } \\
\text { (с откидной койкой) }\end{array}$ \\
\hline
\end{tabular}

Таблица 5

Наличие РКПС у ведущих операторов (на начало 2020 года)

\begin{tabular}{|c|c|c|c|c|c|c|c|}
\hline \multirow[b]{2}{*}{ Судовладелец } & \multicolumn{5}{|c|}{ Возрастные группы судов } & \multirow[b]{2}{*}{$\begin{array}{c}\text { Итого } \\
\text { судов }\end{array}$} & \multirow{2}{*}{$\begin{array}{l}\text { Средний } \\
\text { возраст }\end{array}$} \\
\hline & $\begin{array}{l}\text { менее } \\
10 \text { лет }\end{array}$ & $\begin{array}{c}10-20 \\
\text { лет }\end{array}$ & $\begin{array}{c}21-30 \\
\text { лет }\end{array}$ & $\begin{array}{c}31-40 \\
\text { лет }\end{array}$ & $\begin{array}{l}\text { Свыше } \\
40 \text { лет }\end{array}$ & & \\
\hline «ВодоходЬ» & 1 & & & 16 & 9 & 26 & 37,6 \\
\hline $\begin{array}{l}\text { «Московский } \\
\text { туристический флот» }\end{array}$ & 1 & & 1 & 6 & 6 & 14 & 39,1 \\
\hline «Донинтурфлот» & & & 3 & 4 & 4 & 11 & 36,9 \\
\hline $\begin{array}{l}\text { «Созвездие» } \\
\text { («Инфофлот») }\end{array}$ & & & & 3 & 5 & 8 & 51,0 \\
\hline «ГАMA» & 1 & & & & 6 & 7 & 60,3 \\
\hline $\begin{array}{l}\text { «Viking River Cruises» } \\
\text { («Пассажирский флот») }\end{array}$ & & & 1 & 3 & 1 & 5 & 35,2 \\
\hline «Волга Volga» & & & & & 6 & 6 & 57,5 \\
\hline «Спутник-Гермес» & & & & 1 & 3 & 4 & 53,5 \\
\hline $\begin{array}{l}\text { Итого судов } \\
\text { по возрастным } \\
\text { группам }\end{array}$ & 3 & $\mathbf{0}$ & 5 & 33 & 40 & 81 & 43,0 \\
\hline
\end{tabular}


Утилизация «старых» серий отечественных РКПС не только идет, но и идет с нарастающими темпами. Пик ее пришелся на 2011-2018 годы, и этот процесс продолжается сейчас.

К 2019 году из 254 построенных в советское время речных круизных пассажирских судов 98 (38,6 \%) были списаны (6,7 \% - 17 судов потеряны в катастрофах, утилизировано $31,9 \%$ - 81 судно). В отстое находилось 32 судна (12,6 \%) средним возрастом 57,7 лет. В эксплуатации - формально 124 судна (48,8 \%) средним возрастом 45,2 года, причем из них 4 под иностранным флагом. Средний возраст утилизации 47,1 год.

Прогнозировать выбытие РКПС можно в целом для всего флота, но это будет очень грубой оценкой, так как зависимости выбытия для судов различных проектов значительно отличаются друг от друга и носят вероятностный характер.

Поэтому для каждого проекта, базируясь на данных о списании и опираясь на выбранную модель утилизации («физическое» старение, «моральное» старение, комбинация двух факторов), можно было спрогнозировать сроки списания.

В итоге, в работе [4] был получен следующий прогноз: к 2025 году будет в работе примерно 83 РКПС, в том числе новых, а к 2030 году примерно 51 (без учета судов, которые могут быть за эти годы построены, но пока не заказаны, и без учета байкальских и белорусского РКПС).

При этом можно выделить среди рассматриваемых проектов две большие группы судов (см. таблицы 6 и 7).

Первая (суда проектов 785, 26-37, 588, 305, 646, 860) - это грузопассажирские и пассажирские суда для дальних линий, построенные с начала 50-х до середины $60-\mathrm{x}$ годов прошлого столетия. Круизная функция появилась заметно позже, чем они были приняты в эксплуатацию (достаточно вспомнить, что во многих каютах не было не только индивидуальных санузлов, но и просто умывальников, отсутствовала система кондиционирования). Соответственно, именно к круизным задачам такие суда приспосабливали в разное время и в разном объеме. Кроме того, это относительно небольшие суда с точки зрения главных размерений и количества пассажирских палуб, соответственно, существенно сложнее разместить на них достаточное для прибыльного бизнеса количество комфортабельных кают. Поэтому, например, двухпалубные суда утилизируются гораздо быстрее, чем трехпалубные примерно того же возраста.

Вторая группа судов (проекты 301, 302, Q-040, Q-056, Q-065, 92016) - это суда, которые строились в 70-90-е годы, причем многие уже с учетом круизной функции. Суда этих проектов имели вполне современные архитектурные формы и отличались заметно более высокой комфортабельностью всех пассажирских помещений, имели системы вентиляции и кондиционирования. 
ВІСНИК

ОДЕСЬКОГО НАЦІОНАЛЬНОГО МОРСЬКОГО УНІВЕРСИТЕТУ № 3 (63), 2020
HERALD

OF THE ODESSA NATIONAL

MARITIME UNIVERSITY № 3 (63), 2020

Таблий 6

Средний возраст РКПС по типам (на начало 2020 года)

\begin{tabular}{|l|c|c|c|c|}
\hline \multicolumn{1}{|c|}{ Тип, проект } & $\begin{array}{c}\text { Кол-во } \\
\text { судов, } \\
\text { включая } \\
\text { отстой }\end{array}$ & $\begin{array}{c}\text { Средний } \\
\text { возраст, } \\
\text { включая } \\
\text { отстой, год }\end{array}$ & $\begin{array}{c}\text { Кол-во } \\
\text { судов в } \\
\text { эксплуа- } \\
\text { тации }\end{array}$ & $\begin{array}{c}\text { Средний } \\
\text { возраст в } \\
\text { экплуатации, } \\
\text { год }\end{array}$ \\
\hline «Валериан Куйбышев», 92-016 & 8 & 39,88 & 7 & 39,71 \\
\hline «Дмитрий Фурманов», 302 & 24 & 33,08 & 24 & 33,08 \\
\hline «Владимир Ильич», 301 & 18 & 41,11 & 18 & 41,11 \\
\hline «Дунай», 305 & 21 & 58,23 & 11 & 58,18 \\
\hline «Максим Горький», Q-040 & 4 & 45,50 & 4 & 45,5 \\
\hline «Антон Чехов», Q-056 & 2 & 41,50 & 2 & 41,5 \\
\hline «ергей Есенин», Q-065 & 4 & 35,00 & 3 & 35 \\
\hline $\begin{array}{l}\text { «Октябрьская Революция», } \\
\text { 26-37 }\end{array}$ & 11 & 59,90 & 11 & 59,9 \\
\hline «Родина», 588 & 33 & 61,93 & 24 & 62,12 \\
\hline «Ерофей Хабаров», 860 & 2 & 58,50 & 0 & 0 \\
\hline «Байкал», 646 & 8 & 65,12 & 5 & 65,4 \\
\hline «Россия», 785 & 5 & 64,00 & 0 & 0 \\
\hline «Принцесса Анабелла», 463 & 1 & 47,00 & 1 & 47 \\
\hline $\begin{array}{l}\text { «Сура», ПКС-40 (2 судна } \\
\text { используются как } \\
\text { прогулочные) }\end{array}$ & 1 & 9,00 & 1 & 9 \\
\hline «Рсь Великая», 588/ РЕГК.002 & 1 & 7,00 & 1 & 7 \\
\hline «лександр Грин», РV08 & 1 & 8,00 & 1 & 8 \\
\hline «Штандарт», РV09 & 1 & 3,00 & 1 & 3 \\
\hline «Мустай Карим», РV300 & 1 & 0,00 & 1 & 0 \\
\hline Итого & $\mathbf{1 4 6}$ & $\mathbf{4 9 , 4}$ & $\mathbf{1 1 5}$ & $\mathbf{4 6 , 7}$ \\
\hline
\end{tabular}

В целом в них были заложены правильные конструктивные решения. Они вполне безопасны и эффективны для увеличения уровня комфорта, а в будущем и замены машин и механизмов, что позволит им работать еще примерно 15-20 лет. При этом помимо перепланировочных работ, особо следует ставить вопрос о замене в будущем дизельгенераторов и главных дизелей, ресурс которых практически исчерпан, а заводов, производящих не контрафактные запчасти - уже нет.

С корпусом ситуация иная. Условия эксплуатации таких речных круизных судов гораздо более благоприятны, чем грузовых. Нет смысла сравнивать, например, 40-летнее сухогрузное судно и РКПС такого же возраста. Хорошее техническое обслуживание корпусов, отсутствие загрязнений многих помещений способствует замедлению коррозионного изнашивания. В целом, наблюдения показывают, что скорости коррозионного изнашивания связей пассажирских судов в 2-4 раза меньше скоростей изнашивания связей грузовых судов. 
Распределение РКПС по классам и районам плавания (на начало 2020 года)

\begin{tabular}{|l|c|c|c|c|c|c|c|c|}
\hline \multirow{2}{*}{ Номер проекта } & \multicolumn{7}{|c|}{ Суда с классом РРР } \\
\hline & М-СП & М-ПР & О-ПР & М & О & Р & Л & б/к \\
\hline $26-37,92-055$ & & & & 1 & 10 & & & \\
\hline 301 & & & & 17 & & & & 1 \\
\hline $302,302 \mathrm{M}$ & & & 1 & 20 & & & & 2 \\
\hline 305 & & & & & 12 & & & 16 \\
\hline 588 & & & & 2 & 22 & & & 11 \\
\hline 646 & & 1 & & 4 & 1 & & & 2 \\
\hline 785 & & & & & 3 & & & 6 \\
\hline 860 & & & & & & & & 2 \\
\hline 463 & & & & & 1 & & & \\
\hline $92-016$ & & & & 7 & & & & 2 \\
\hline ПКС-40 & & & & & 1 & 2 & & \\
\hline 588 / РЕГК.002 & & 1 & & & & & & \\
\hline РV08 & & & & 1 & & & & \\
\hline РV09 & & 1 & & & & & & \\
\hline Q-040 & & & & 4 & & & & \\
\hline Q-056 & & & & 2 & & & & \\
\hline Q-065 & & & & 1 & 1 & & & 2 \\
\hline Всего, 160 единиц флота & 0 & 3 & 1 & 59 & 51 & 2 & 0 & 44 \\
\hline Всего, \% & - & $\mathbf{1 , 9}$ & $\mathbf{0 , 6}$ & $\mathbf{3 6 , 9}$ & $\mathbf{3 1 , 9}$ & $\mathbf{1 , 3}$ & - & $\mathbf{2 7 , 5}$ \\
\hline
\end{tabular}

Например, все 4 четырехпалубных судна проекта Q-040 типа «Максим Горький» (строились в Корнойбурге, Австрия в 1974-1975 годах), а также оба судна проекта Q-056 типа «Антон Чехов» (строились там же в 1978-1979 годах) эксплуатируются. Средний возраст судов проекта Q-040 - 44,5 года, проекта Q-056 - 40,5 лет.

Из 9 четырехпалубных судов проекта 92-016 типа «Валериан Куйбышев» (строились в Комарно, Словакия в 1975-1983 годах) списано $11,1 \%$ - 1 судно (причем судно было списано для получения утилизационного гранта для финансирования постройки нового круизного пассажирского судна проекта PV300). В отстое 1 судно $(11,1 \%)$ с возрастом 42 года. В эксплуатации 7 судов $(77,8 \%)$ средним возрастом 38,6 лет. Средний возраст утилизации - 43 года. Особенностями проекта являются достаточно большие площади палуб, что выгодно может быть использовано при модернизации, так как исходная планировка кают требует существенного вмешательства (25 кают сейчас трехместные, $40-$ 
узкие двухместные); недостаточная площадь ресторана (питание в две смены); малая мощность подруливающего устройства; при постройке класс «О» (Ладога и Онега - класс «М»). Но в целом суда проекта 92-016 могут быть эффективными донорами для крупных модернизаций с перепланировкой и заменой оборудования.

Из 22 четырехпалубных судов проекта 301 типа «Владимир Ильич» (строились в Бойценбурге, Германия в 1975-1983 годах) списано 9,1 \% - 2 судна. В отстое судов нет. В эксплуатации 20 судов (90,9 \%), включая 2 в Украине, средним возрастом 40,3 года. Средний возраст утилизации - 26 лет (оба списанных судна работали за границей).

Из 24 судов (за исключением 3 судов проекта 302МК, работающих в Китае) проекта 302 типа «Дмитрий Фурманов» (строились в Бойценбурге, Германия в 1983-1991 годах) ни одного судна не списано, также нет судов в отстое. В эксплуатации все суда серии средним возрастом 32,1 год.

Из 5 трехпалубных судов проекта Q-065 типа «Сергей Есенин» (строились в Корнойбурге, Австрия в 1984-1986 годах) списано 20,0 \% 1 судно (элементы были использованы для постройки РКПС проекта PV08). В отстое 1 судно (20,0 \%) возрастом 34 года. В эксплуатации 3 судна (60,0 \%) средним возрастом 34 года. Средний возраст утилизации - 27 лет. Серия предназначалась для работы на линиях с малыми глубинами. С целью снижения массы судна порожнем обычно применяемые на РКПС среднеоборотные дизеля на них были заменены на высокооборотные, которые обладали повышенным расходом топлива и относительно меньшим ресурсом.

РКПС переоборудовались (и переоборудуются) с целью повышения уровня комфорта, что приводит к сокращению пассажировместимости (числа кают) за счет увеличения площади кают [5].

Но далеко не все существующие РКПС переоборудованы и модернизированы под современные понятия круизного судна, да и, не все проекты одинаково подходят для переоборудования, затраты могут достигать 30-50 \% от стоимости нового судна, как следствие - утилизация определенной части РКПС.

Работы по модернизации и конверсии на таких судах проводятся, в первую очередь, для повышения комфортабельности круизов. Учитывая, зачастую, невозможность изменения габаритных размерений на РКПС, единственным возможным вариантом остается уменьшение пассажировместимости.

При этом происходит перераспределение площадей по сравнению с базовыми проектами: увеличивается удельная площадь кают с 2,04,5 м²/чел до 9,0-12,0 м²/чел, удельная площадь общественных помещений с 4,5-9,0 м²/чел до 11,5-16,0 м²/чел.

Кроме того, увеличивается также количество экипажа и обслуживающего персонала на одного пассажира до 0,51. 
ВІСНИК

ОДЕСЬКОГО НАЦІОНАЛЬНОГО

МОРСЬКОГО УНІВЕРСИТЕТУ № 3 (63), 2020
HERALD

OF THE ODESSA NATIONAL

MARITIME UNIVERSITY № 3 (63), 2020

Так, например, теплоход «Комарно» проекта 26-37 построенный в 1959 году, с 2005 по 2007 год был подвергнут существенной модернизации. В результате «Волга Дрим» (новое название судна) превратился в одно из самых комфортабельных судов на Волге. При этом общее число кают сократилось со 117 до 58 и соответственно количество пассажиров с 312 до 109 мест.

Для работы с иностранцами как с наиболее выгодным сегментом туристического бизнеса, переоборудование предполагает повышение уровня комфортабельности КС до уровня $4 *$ отеля. Проведение таких работ целесообразно только для относительно новых и достаточно больших РКПС, у которых еще не выработан технический ресурс судовых машин, механизмов, систем. Для четырехпалубных судов численность пассажиров в таких современных каютах составляет 200-220 человек. Например, на «Княжне Виктории» проекта 301 после модернизации 109 кают (218 пассажиров). На судне проекта PV17 «Викинг Синеус» (модернизация судна проекта 301 «Михаил Ломоносов», см. рисунок 2) - 196 пассажиров. На РКПС «Мстислав Ростропович» проекта 92-016 пассажировместимость после переоборудования - 212 человек.

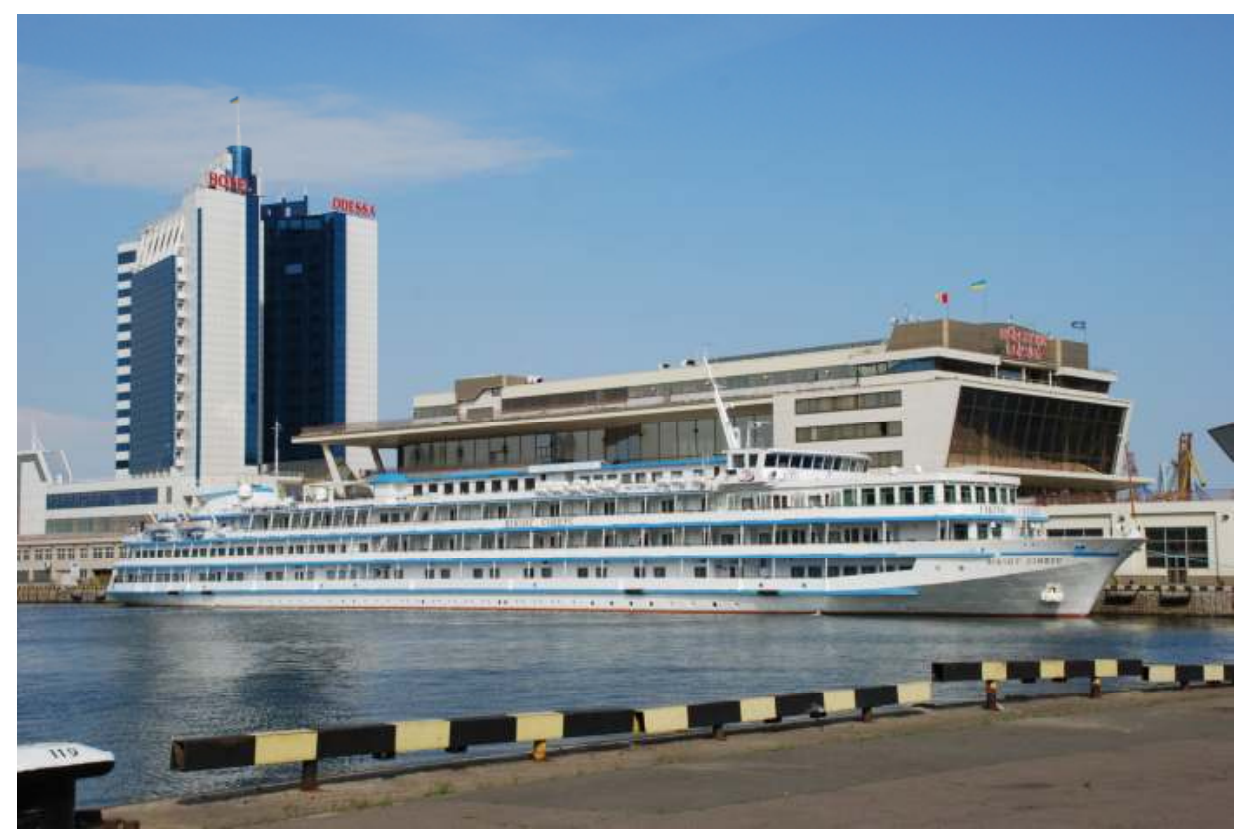

Рис. 2. Модернизированное круизное судно «Викинг Синеус» проекта PV17 в Одессе. Длина 125 м. 196 пассажиров / 98 кают.

Модернизация в 2013-2014 году 
В итоге, общая пассажировместимость отечественных РКПС, при этом, продолжает снижаться как за счет списания судов, так и за счет уменьшения числа мест при повышении комфортабельности во время переоборудования. Практически все суда в той или иной степени были переоборудованы или модернизированы.

Существенно модернизировано с повышением уровня комфортабельности 43 круизных пассажирских судна $(38,7$ \% от всех работающих в навигацию 2019 года).

На 12 круизных пассажирских судах (10,8\% от всех работающих) были установлены балконы на всех палубах, на 9 судах - балконы установлены частично (для определенной категории номеров, чаще всего, для кают класса «Люкс»).

Работы по модернизации и переоборудованию продолжаются. За крайние пять лет было модернизировано 34 судна.

В межнавигационный период 2018-2019 года активно работали над повышением комфортабельности компании «ВодоходЂ» (т/х «Нижний Новгород» и т/x «Санкт-Петербург»), «Мостурфлот» (т/x «Сергей Есенин», т/x «А.С. Пушкин», т/x «Россия»), «Инфофлот» (т/x «Василий Чапаев», $\mathrm{T} / \mathrm{x}$ «Северная сказка»), «Донинтурфлот» (т/x «Игорь Стравинский») и «Белый лебедь» (т/х «Бородино», т/x «К.А. Тимирязев»).

На рынок вышла швейцарская компания Thurgau Travel, для которой в межнавигационный период 2018-2019 годов были модернизированы сразу 2 РКПС, в том числе теплоход «А.С. Попов» компании «ГАМА»первое судно проекта 588 с балконами не только для кают класса «Люкс». На обновленном судне 71 каюта площадью 14-16 м² и 10 кают площадью 11-14 м², при этом количество пассажиров сократилось до 162 с 339 человек (на 52,2 \%). По внутренней классификации оператора судно категории 3+*. Были установлены санблоки, многоканальные сплитсистемы кондиционирования, новые вентиляторы, заменены кабельные трассы и электрощиты, установлена новая автоматика на судовую электростанцию.

Второй - теплоход «Ремикс» («Remix») - судно проекта 305 для работы на линии Салехард - Новосибирск (река Обь). На обновленном судне каюты площадью от 10 до 60 кв. м, количество пассажиров сократилось до 53 с 311 человек (на 83 \%). По внутренней классификации оператора судно категории $3 *$.

Общая пассажировместимость на 2019 год составляет 24602 человек. К 2030 году прогнозируется уменьшение пассажировместимости на $52,72 \%$ до 11631 человека (без учета возможного уменьшения пассажировместимости за счет глубокой модернизации других круизных судов и нового пополнения).

Работают новые суда - 3 пассажирских судна с колесным движительно-рулевым комплексом проекта ПКС-40 типа «Сура» средним возрастом 6,7 лет, 1 конверсионное судно проекта 588 / РЕГК.002 типа 
ВІСНИК

ОДЕСЬКОГО НАЦІОНАЛЬНОГО

МОРСЬКОГО УНІВЕРСИТЕТУ № 3 (63), 2020
HERALD

OF THE ODESSA NATIONAL

MARITIME UNIVERSITY № 3 (63), 2020

«Русь Великая» возрастом 7 лет, 1 конверсионное судно проекта PV08 типа «Александр Грин» возрастом 8 лет [6], а также новое высококомфортабельное судно проекта PV09 типа «Штандарт» возрастом 3 года и новое судно проекта PV300 «Мустай Карим» (сдано в 2020 году).

На трехпалубном судне проекта PV08 «Александр Грин» [6] (новое судно, построенное с использованием элементов существующего судна проекта Q-065) для размещения 112 пассажиров созданы 56 стандартных кают площадью 14,5-18 м² и 6 улучшенных кают класса «Люкс» площадью 23-25 м² (все с двуспальными кроватями, душем и туалетом, кондиционером, шкафами, сейфом, телевизором со спутниковыми и внутрисудовыми каналами, феном, электрическими розетками на $220 \mathrm{~B}$, беспроводным Интернетом, судовой радиотрансляцией, внутренней и внешней телефонной связью). Каюты на двух палубах имеют индиивидуальные балконы (со сдвижными перегородками, обеспечивающими свободный проход по палубам вдоль всего судна в аварийных ситуациях). Полностью новыми являются системы кондиционирования, водоснабжения и вентиляции, главные и вспомогательные дизеля, электро-радиона-

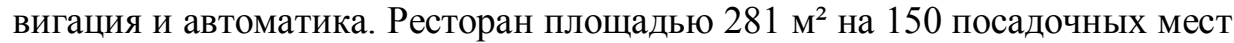
обеспечивает питание в одну смену, салон с баром на 65 мест площадью $221 \mathrm{~m}^{2}$, спортзал, массажная, сауна, парикмахерская, амбулатория.

Построенное в 2017 году круизное судно смешанного река-море плавания проекта PV09 стало прототипом для концепта PV300VD (cм. рисунок 3). Это, по сути, начало той «линейки» круизных судов, к постройке которых приступили астраханский завод «Лотос» и нижегородский завод «Красное Сормово».

PV09

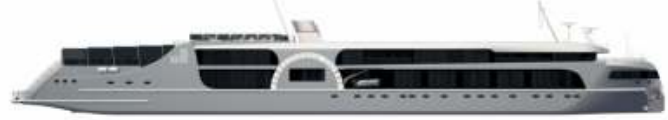

PV300VD

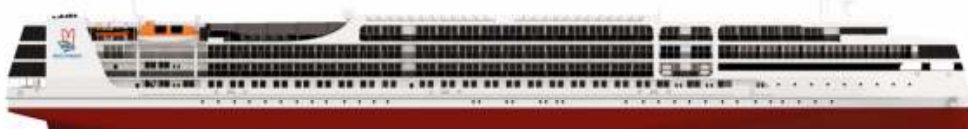

PV300

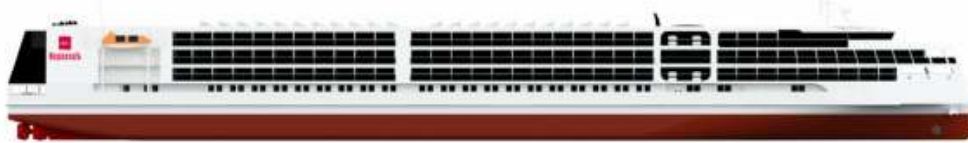

PV11M

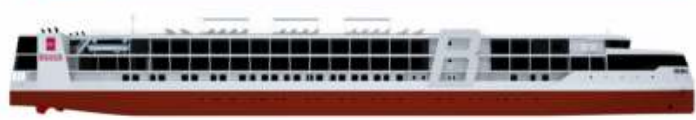

25

50

75

100

125

150

Рис. 3. Линейка круизных пассажирских судов нового поколения 2019 года 
Все главные общепроектные решения концепта PV300 и PV300VD были отработаны на PV09, в том числе архитектура и особенно боковой вид, свойственный яхтами и круизным судам XXI века; помещения и каюты с максимальным остеклением (большими окнами); «плавучая гостиница» с устройством полноценных балконов, носовым обзорным салоном; двухуровневой «солнечной» палубой с баром, бассейном, в плохую погоду часть палубы закрывается при помощи сдвижного тента; дизель-электрическая пропульсия; полноповоротные винто-рулевые колонки в качестве единого средства движения и управления судном.

Принципиальным являлся вопрос об обеспечении реализации вырезов под окна и двери практически от палубы до палубы, что требовало решения ряда проблем по прочности узлов крепления, материала окон, обеспечения взаимодействия палуб при минимальных площадях стенок рубок, наконец, водо-и брызгонепроницаемости (в зависимости от палубы).

Крайне сложным было сочетание ограничения по осадке и длине (для работы на реке Ока), по надводному габариту (для прохода под мостами на Москве-реке в центральной части города), по ширине судна (для работы на ББК).

Круизное пассажирское судно проекта PV09 предназначено для совершения круизных рейсов по европейским внутренним водным путям, в том числе через Волго-Балт, Волго-Дон, Беломорско-Балтийский канал, по Волге, Москве-реке, на линиях, соединяющих порт Москва, порт Санкт-Петербург и порт Беломорск через Беломорско-Балтийский канал, с возможностью выхода в Белое море и на Соловецкие острова, в Финский залив, Каспийское, Азовское и Черное моря.

Надводный габарит судна обеспечивает возможность прохода под мостами р. Москва в центральной части города.

В постройке находятся новые пассажирские круизные суда проекта ПКС-180 (2 единицы, сдача в эксплуатацию планируется в 2021 году) PV300VD «Петр Великий» (спущен на воду, сдача в эксплуатацию планируется в 2022 году). Новые концепты имеют вполне приемлемые осадки: PV09 - 1,80 м, PV300VD - 3,20 м, PV300 - 3,00 м и что их «Пятизвездочные» возможности востребованы как иностранными, так и отечественными туристами.

Новые суда, благодаря высокому уровню автоматизации, должны обслуживаться сокращенным штатом экипажа, что положительно повлияет на экономические показатели работы.

Проекты PV300 / PV300VD были разработаны в 2010-2015 годах Морским Инженерным Бюро.

Четырехпалубный круизный лайнер проекта PV300 «Мустай Карим» (см. рисунки 4 и 5) рассчитан на 329 пассажира, размещаемых в комфортабельных двухместных каютах (в семи каютах три места - два взрослых плюс ребенок) площадью от 17 до 46 м². 
ВІСНИК

ОДЕСЬКОГО НАЦІОНАЛЬНОГО

МОРСЬКОГО УНІВЕРСИТЕТУ

№ 3 (63), 2020
HERALD

OF THE ODESSA NATIONAL

MARITIME UNIVERSITY № 3 (63), 2020
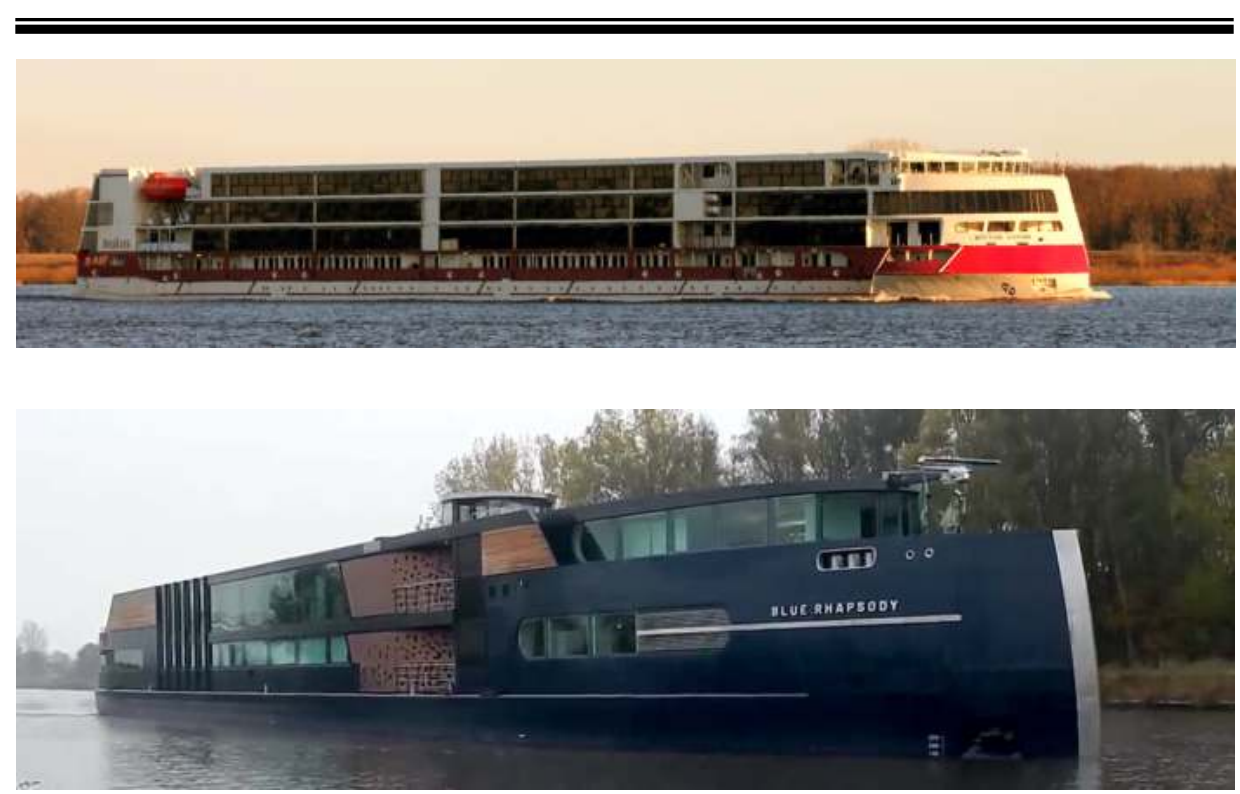

Рис. 4. Пассажирские суда современных очертаний на Волге и на Рейне - PV300 Myстай Карим (2020) и Blue Rhapsody (2019)
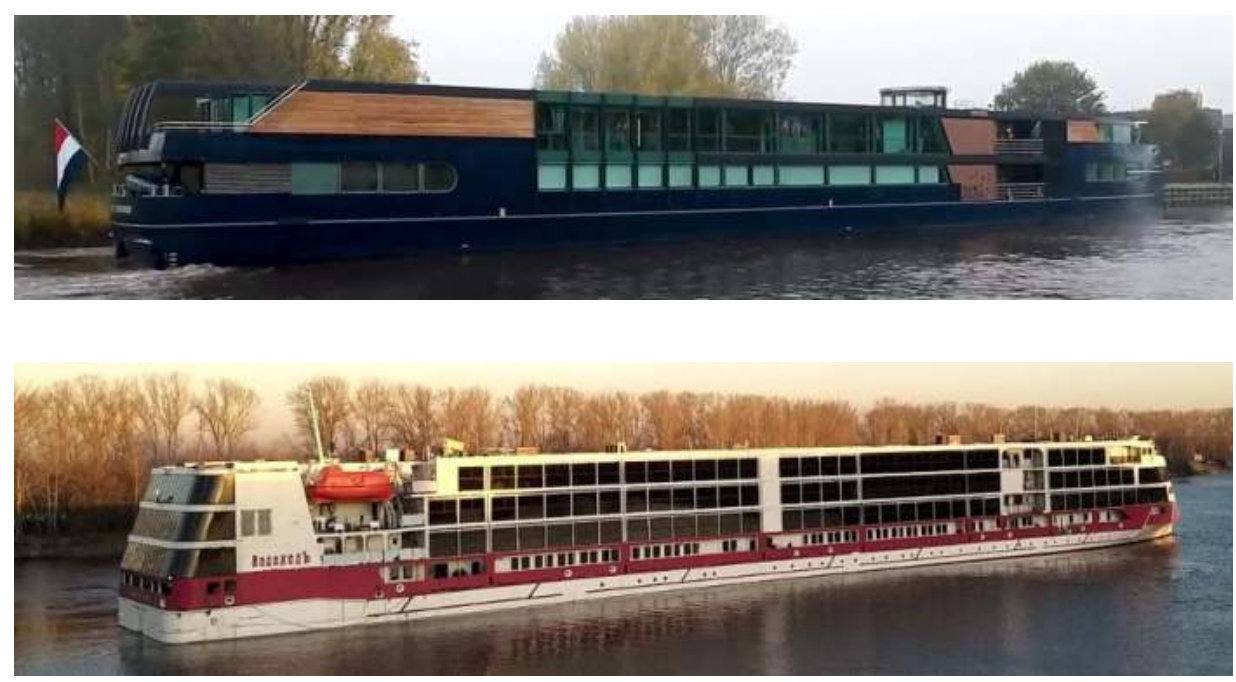

Рис. 5. Пассажсирские суда современных очертаний на Волге и на Рейне - PV300 Мустай Карим (2020) и Blue Rhapsody (2019)

Судно приступило к работе в 2020 году на дальних круизных линиях Москва - Санкт-Петербург, Москва - Астрахань и Москва Ростов-на-Дону, по Азовскому и Черному морю по классу М-ПР 3,0.

Судно обладает «всеми атрибутами пятизвездочного отеля», включая поддерживающую пассажирскую инфраструктуру. 
Ресторан на главной палубе имеет 329 посадочных мест, т.е. обеспечивает единовременную посадку всех гостей, включая детей.

Для досуга есть обзорные салоны (музыкальный на 200 мест и читальный на 50 мест), трансформируемый конференц-зал (на 140 мест), три бара (пивной, «Панорама» и в читальном салоне), детская комната, фитнесс-центр (сауна, хамам, массажные кабинеты, тренажерный зал, парикмахерская), сувенирный киоск и солярий на открытой солнечной палубе $\left(700 \mathrm{M}^{2}\right)$.

Для привычных судов «Волго-Дон макс» класса существующих проектов (пр. 301, 302) численность пассажиров в таких современных каютах составляет 200-220 человек. В новом концепте PV300, имеющем такие же примерно габаритные размеры, можно очень комфортно разместить примерно 300-350 пассажиров.

Все пассажирские каюты размещены на верхней, шлюпочной и тентовой палубах. На главной палубе, где члены экипажа работают при швартовке, шлюзовании, высадке пассажиров, приеме грузов и где, соответственно, может быть повышенный уровень шума и вообще могут возникать факторы, беспокоящие клиентов пассажирских кают - нет.

Компоновка круизного пассажирского судна в варианте Водохода рассчитана на 329 пассажира, которые путешествуют в комфортабельных 161 каютах: 7 трехместных каютах «Люкс» площадью 29-46 м², 2 двухместных каютах «Люкс» площадью по 24 м $^{2}$ и 152 каютах «Стандарт» площадью около 17-20 м².

Все каюты имеют собственные «французские» балконы (некий аналог лоджии), оборудованы двуспальными кроватями, душем с туалетом, кондиционером, шкафами, сейфом, телевизором со спутниковыми и внутрисудовыми каналами, феном, электрическими розетками на $220 \mathrm{~B}$ и $110 \mathrm{~B}$, беспроводным Интернетом (Wi-Fi), судовой радиотрансляцией, внутренней и внешней телефонной связью.

Концепт PV300VD «Петр Великий» будет работать с 2022 года на линии Москва - Санкт-Петербург, а также совершать рейсы Москва Ростов-на-Дону - Сочи, Астрахань - порты Каспия, т.е. по классификации Морского Инженерного Бюро - это судно «Волго-Дон макс» класса.

Компоновка круизного пассажирского судна «Петр Великий» в варианте Московского речного пароходства рассчитана на 310 пассажиров, которые путешествуют в комфортабельных 155 каютах различных классов:

- 7 «люкс» апартаментов с балконом площадью около 36-43 м² (33-35 м² без учета балкона);

- 5 «люкс» кают с балконом площадью около $26 \mathrm{~m}^{2}\left(21 \mathrm{~m}^{2}\right.$ без учета балкона);

- 133 стандартные каюты с балконом площадью около 19-21 м² (16-18 м² без учета балкона);

- 8 стандартных кают площадью около 16 м²; 
- 2 стандартные каюты для людей с ограниченными возможностями площадью около $21 \mathrm{~m}^{2}$.

Каюты пассажиров размещаются в средней вертикальной зоне на 4-х ярусах надстройки, каюты на 3-х верхних ярусах имеют собственные балконы со сдвижными секциями для обеспечения сквозного прохода по палубе в аварийных ситуациях.

Все пассажирские каюты оборудованы двуспальными кроватями, душем с туалетом, кондиционером, шкафами, сейфом, телевизором со спутниковыми и внутрисудовыми каналами, феном, электрическими розетками на $220 \mathrm{~B}$ и $110 \mathrm{~B}$, беспроводным Интернетом (Wi-Fi), судовой радиотрансляцией, внутренней и внешней телефонной связью.

На судне предусмотрено питание всех пассажиров в одну смену. Для этого предусмотрены два ресторана: главный ресторан и ресторан с открытой кухней.

Главный ресторан имеет два зала площадью $360 \mathrm{M}^{2}$ и $140 \mathrm{~m}^{2}$, каждый зал снабжен шведской линией. Большой зал оборудован барной стойкой. В ресторане с открытой кухней есть возможность наблюдать за приготовлением пищи, камбуз отделен от ресторана стеклянной выгородкой. Все рестораны имеют максимальное остекление, что позволяет наслаждаться не только вкусной едой, но и видом из окон.

24 часа бар работает до последнего клиента. Вечером дискотека, днем бар, расположение бара не мешает отдыхать другим пассажирам. Рядом разместилась двухуровневая солнечная палуба с гриль баром, бассейном и джакузи, в плохую погоду часть палубы закрывается при помощи сдвижного тента.

Концепт PV300VD - это не только современное высококомфортабельное и удобное, но и безопасное, экологически «чистое» пассажирское судно, полностью отвечающее всем Международным конвенциям (МК), включая МК по охране человеческой жизни на море СОЛАС, МК по предотвращению загрязнения с судов МАРПОЛ, Международные правила предупреждения столкновения судов в море МППСС, а также всем национальным требованиям (Санитарным Правилам и нормам, Правилам пожарной безопасности, Техническому регламенту о безопасности объектов внутреннего водного транспорта).

Но их, этих новых судов, крайне мало.

Для сохранения понятия «речной круиз», и не только для иностранных туристов, рекомендуется на среднесрочную и долгосрочную перспективы строительство новых пассажирских судов, которые бы наиболее полно удовлетворяли запросам рынка. Это могут быть круизные пассажирские суда как для классических речных маршрутов в европейской части страны (PV300, PV500VB, PV09, ПКС-180 и т.п.), так и смешанного плавания суда для работы в прибрежных морях и на речных маршрутах, в том числе, на Енисее, Лене, Оби и Амуре (PV300VD, PV11 и т.п.). 
В пересчете затрат на одну каюту строительство нового судна в России обходится в $\$ 500$ тыс., конверсия (с использованием существующих элементов) - \$200 тыс., модернизация на премиум-сегмент $\$ 100$ тыс., а обычная модернизация - \$30-50 тыс. При этом в Германии строительство нового судна в пересчете на стоимость одной каюты составляет $\$ 350$ тыс.

Заключение. Число отечественных речных круизных пассажирских судов к 2025 году сократится почти на $30 \%$, до 87 единиц (с учетом нового флота). К 2030 году его количество может уменьшиться до 53 судов без учета судов, которые могут быть построены.

Сейчас количество действующих судов составляет 124 судна, средний возраст которых около 47 лет. При этом на фоне модернизации судов будет наблюдаться сокращение пассажировместимости. Так, если в 2019 году этот показатель составил 24,6 тыс. человек, то к 2025 году он снизится до 18,8 тыс. человек, а к 2030 году может упасть до 11,6 тыс. пассажиров.

Работают новые суда - 3 пассажирских судна с колесным движительно-рулевым комплексом проекта ПКС-40 типа «Сура» средним возрастом 6,7 лет, 1 конверсионное судно проекта 588/РЕГК.002 типа «Русь Великая» возрастом 6 лет, 1 конверсионное судно проекта PV08 типа «Александр Грин» возрастом 8 лет, а также новое высококомфортабельное судно проекта PV09 типа «Штандарт» возрастом 3 года и новое судно проекта PV300 «Мустай Карим» (сдано в 2020 году).

В постройке находятся новые пассажирские круизные суда проекта ПКС-180 (2 единицы, сдача в эксплуатацию планируется в 2021 году), PV300VD «Петр Великий» (спущен на воду, сдача в эксплуатацию планируется в 2022 году). Новые концепты имеют вполне приемлемые осадки: PV09 - 1,80 м, PV300VD - 3,20 м, PV300 - 3,00 м и что их «Пятизвездочные» возможности востребованы как иностранными, так и отечественными туристами.

Для сохранения понятия «речной круиз», и не только для иностранных туристов, рекомендуется на среднесрочную и долгосрочную перспективы строительство новых пассажирских судов, которые бы наиболее полно удовлетворяли запросам рынка. Это могут быть круизные пассажирские суда как для классических речных маршрутов в европейской части страны и на Днепре (PV300, PV500VB, PV09, ПКС-180 и т.п.), так и смешанного плавания суда для работы в прибрежных морях и на речных маршрутах, в том числе, на Енисее, Лене, Оби и Амуре (PV300VD, PV11 и т.п.).

В пересчете затрат на одну каюту строительство нового судна обходится в $\$ 500$ тыс., конверсия (с использованием существующих элементов) - \$200 тыс., модернизация на премиум-сегмент - \$100 тыс., а обычная модернизация - \$30-50 тыс. При этом в Германии строительство нового судна в пересчете на стоимость одной каюты составляет $\$ 350$ тыс. 


\section{СПИСОК ЛІТЕРАТУРИ}

1. Market Observation for inland navigation in Europe. Annual report 2019. Edited by the Secretariat of the Central Commission for Navigation on the Rhine. Strasbourg, September, 2019. $176 \mathrm{p}$.

2. Егоров Г.В. Анализ опыта европейских речных круизов и его влияние на новое поколение отечественных пассажирских судов // Морской вестник. 2012. № 3 (43). С. 23-28.

3. Егоров Г.В., Егоров А.Г. Современные тендениии на мировом круизном флоте // www. korabel.ru. 2019. Bып. 2 (44). C. 16-28.

4. Егоров А.Г. Определение фактической пассажировместимости отечественных речных круизных пассажирских судов с прогнозом до 2030 года // Морской Вестник. 2019. № 4 (72). C. 7-11.

5. Егоров А.Г. Особенности компоновки пассажирского $u$ служебного блоков на речных круизных пассажирских судах $c$ учетом модернизаций и конверсий // Труды КГНЦ. СПб.: Крыловский государственный научный иентр, Спец. выпуск №1, 2020. C. 154-163.

6. Егоров А.Г. Приниипы проектирования речных круизных судов с использованием судов-доноров // Морской Вестник. 2019. № 3 (71). C. 9-15.

\section{REFERENCE}

1. Secretariat of the Central Commission for Navigation on the Rhine (2019) Market Observation for inland navigation in Europe. Annual report 2019. - Strasbourg, $176 \mathrm{p}$.

2. Egorov, G.V. (2012). Analiz opyta evropeyskikh rechnykh kruizov $i$ ego vliyaniye na novoye pokoleniye otechestvennykh passazhirskikh sudov [Analysis of the experience of European river cruises and its impact on a new generation of domestic passenger ships]. Morskoy Vestnik (Maritime Reporter), 3 (43), 23-28 [in Russian].

3. Egorov, G.V., Egorov, A.G. (2019). Sovremennyye tendentsii na mirovom kruiznom flote [Current trends in the global cruise fleet]. www.korabel.ru zhournal (www.korabel.ru journal), 2 (44), 16-28 [in Russian].

4. Egorov, A.G. (2019). Opredeleniye fakticheskoy passazhirovmestimosti otechestvennykh rechnykh kruiznykh passazhirskikh sudov s prognozom do 2030 goda [Determination of the actual passenger capacity of domestic river cruise passenger ships with a forecast up to 2030]. Morskoy Vestnik (Maritime Reporter), 4 (72), 7-11. [in Russian]. 
ВІСНИК

ОДЕСЬКОГО НАЦІОНАЛЬНОГО

МОРСЬКОГО УНІВЕРСИТЕТУ

№ 3 (63), 2020
HERALD

OF THE ODESSA NATIONAL

MARITIME UNIVERSITY

№ 3 (63), 2020

5. Egorov, A.G. (2020). Osobennosti komponovki passazhirskogo $i$ sluzhebnogo blokov na rechnykh kruiznykh passazhirskikh sudakh $s$ uchetom modernizatsiy $i$ konversiy [Features of design of the passenger and service zones on river cruise passenger ships with taking into account modernizations and conversions]. Trudy Krylovskogo gosudarstvennogo nauchnogo tsentra (Proceedings of Krylov State Research Center), Special Volume 1, 154-163. [in Russian].

6. Egorov, A.G. (2019). Printsipy proyektirovaniya rechnykh kruiznykh sudov s ispolzovaniyem sudov-donorov [Design principles of river cruise ships with usage of donor ships]. Morskoy Vestnik (Maritime Reporter), 3 (71), 9-15 [in Russian].

Стаття надійшла до редакиії 15.04.2020

Посилання на статтю: Егоров А.Г. Анализ перспектив строительства новых речных круизных судов // Вісник Одеського національного морського університету: Зб. наук. праць, 2020. № 3(63). C. 51-75. DOI 10.47049/2226-18932020-3-51-75.

Article received 15.04.2020

Reference a JournalArtic: Egorov A. Analysis of perspectives of building of new river cruise vessels // Herald of the Odessa national maritime university. 2020. 3(63), 51-75. DOI 10.47049/2226-1893-2020-3-51-75. 